\title{
Fermentation of milk- and water-based amaranth mashes
}

\author{
Zuzana Matejčeková, Denisa Liptáková, L’ubomír Valík \\ Department of Nutrition and Food Assessment, Faculty of Chemical and Food Technology, \\ Slovak University of Technology in Bratislava, Radlinského 9, SK-812 37 Bratislava, Slovak republic \\ zuzana.matejcekova@stuba.sk
}

\begin{abstract}
Growth dynamics of lactic acid bacteria (LAB) of the culture Fresco DVS 1010 and Lactobacillus rhamnosus GG in milk- and water-based amaranth mashes with sucrose or flavouring compounds (chocolate, caramel) were evaluated in this study. After fermentation that was performed at $37 \pm 1^{\circ} \mathrm{C}$ for $8 \mathrm{~h}$ in $\mathrm{CO}_{2}$ incubator $(5 \%)$ the products were kept at $6 \pm 1{ }^{\circ} \mathrm{C}$ for 2 weeks. The content of proteins, lipids, reducing sugars, and starch of used amaranth flours was determined before and after expiry date, to evaluate the differences in main nutritional components. The results showed that all amaranth substrates were suitable for fermentation as the LAB levels from $10^{8}$ to $10^{9} \mathrm{CFU} \cdot \mathrm{ml}^{-1}$ were reached and the levels higher than $10^{6} \mathrm{CFU} \cdot \mathrm{ml}^{-1}$ remained during cold storage. The presence of milk compared to water had no significant impact on the growth rates of LAB under study. Sensory value of flavoured amaranth mashes after the $8 \mathrm{~h}$ fermentation, and after 7 and 14 days of refrigerated storage was part this study as well. The best sensory acceptance according to the final evaluation of overall acceptability was evaluated in case of milk amaranth chocolate mash after 7 days of storage.
\end{abstract}

Keywords: amaranth, fermentation, lactic acid bacteria

\section{Introduction}

Nowadays, it is known several species of amaranth, but only few of them are used in food sector. Grains of amaranth are small with size to $1.5 \mathrm{~mm}$ and are characterized with balanced composition of essential amino acids, higher content of proteins (15-17\%) and starch (60-65\%) (Amicarelli and Camaggio, 2012; Bhat et al., 2014). Compared to other cereals, seeds of amaranth are also rich source of vitamins (riboflavin, niacin, vitamin E) and minerals (calcium, magnesium) (Sterr et al., 2009). Due to its advantageous nutritional properties this crop could represent a good option for usage in cereal technology and in producing gluten-free products (Mlakar et al., 2010). High nutritional quality of this crop can be even improved by the fermentation process, which is influenced by the activities of microorganisms and enzymes. Also internal and external environmental factors such as variability of crops and their chemical composition affect the growth and metabolism of lactic acid bacteria during fermentation (Marko et al., 2014). Incorporation of lactic acid bacteria to pseudo-cereal substrates improves the organoleptic quality of final fermented products, such as taste or flavour, due to the production of compounds like alcohols or organic acids (Kocková et al., 2013).

Some strains of lactic acid bacteria used for fermentation have beneficial effect on host health by improving intestinal microbial balance are called probiotics. They are called probiotics. The most common microorganisms used in probiotics preparations are Lactobacillus species such as Lb. acidophilus, Lb. casei,
Lb. rhamnosus or Bifidobacterium species such as $B$. longum, B. breve or B. lactis (Charalampopoulos et al., 2002). Lactobacillus rhamnosus $G G$ is one of the most monitored probiotic strains. It belongs to Grampositive, catalase-negative, non-motile, non-spore forming, mesophilic bacteria. During fermentation process can produce lactic acid, acetic acid, formic acid, and ethanol (Curry and Crow, 2002). In addition, other primary or secondary antimicrobial metabolites, such as diacetyl, hydrogen peroxide, acetoin, or bacteriocins act in control of the growth and multiplication of pathogenic and spoilage microorganisms synergistically with decreasing $\mathrm{pH}$ value (Liptáková et al., 2010).

$L b$. rhamnosus GG is able to survive the intestinal passage, is tolerant to acidic environment of the stomach, and has the ability to adhere to intestinal mucosa. This probiotic strain may be used in food industry as a protective culture in fermented and non-fermented dairy products, or even in salads and beverages because of its antimicrobial activities (Kocková et al., 2013). Majority of food-containing probiotic bacteria originate from milk, so they are not accepted by people suffering from intolerances or milk allergies. Therefore, we focused our effort on the analysis of growth of lactic acid bacteria in amaranth water, or milk products, which are also suitable for people with celiac disease.

\section{Materials and Methods}

Microorganisms. The probiotic strain Lb. rhamnosus GG was provided by Dr. Salminen and Ouwehand 
(University of Turku, Finland) and was delivered through mediation of Dr. Lauková (State Veterinary and Food Institute, Košice, Slovakia). Fresco DVS 1010 culture (consists of Lactococcus lactis spp. lactis, Lactococcus lactis spp. cremoris, Streptococcus thermophilus) is commercial culture from Christian and Hansen (Hørsholm, Denmark) and was provided by Rajo a.s. (Bratislava, Slovakia).

Inoculation and cultivation conditions. Pure culture of Lb. rhamnosus GG was kept in MRS broth (Biokar Diagnostics, Beauvais, France) at $5 \pm 1{ }^{\circ} \mathrm{C}$. The standard suspension of the microorganism was prepared from a $24 \mathrm{~h}$ culture of selected strain of lactobacilli grown in MRS broth at $37^{\circ} \mathrm{C}\left(5 \% \mathrm{CO}_{2}\right)$. Fresco DVS 1010 culture was kept in a deep-freezer. The standard suspension was prepared from a $24 \mathrm{~h}$ culture grown in M17 broth (Biokar Diagnostics, Beauvais, France) and was incubated at $30^{\circ} \mathrm{C}$. Pure $24 \mathrm{~h}$ cultures of studied lactic acid bacteria were centrifuged (6000 rpm for 5 minutes), washed in $10 \mathrm{ml}$ of sterile distilled water and centrifuged again under the same conditions. After centrifugation, supernatant was decanted and pellets were resuspended in distilled water to its original volume (Angelov et al., 2006).

Pseudocereal substrate. Pseudo-cereal amaranth flour was used in this work (obtained from mill house Mlyn Zrno, Šišov, Slovakia). To maintain the same consistency of amaranth mashes the content of flour was $14 \%$ in milk based preparation and $20 \%$ in those prepared with water. Sucrose was added (2 \%) to both preparations. Flavoured amaranth products were prepared by substitution of sucrose with flavours (chocolate or caramel) (obtained from Rajo a.s., Bratislava, Slovakia). The ratio of pseudo-cereal mash and flavouring compounds was $80 \%: 20 \%$. When milk substrates were tested, the content of flour was $11.2 \%$. The latest was $16 \%$ when water substrates were used, in order to maintain the same consistency of products.

Fermentation and storage. Amaranth substrates were boiled at $100{ }^{\circ} \mathrm{C}$ for 20 minutes while stirred. Then, they were sterilized at $121^{\circ} \mathrm{C}$ for 20 minutes. Subsequently, they were cooled down and the $20 \%$ of flavour (chocolate, caramel) was added. Preparations were inoculated with $5 \%$ of starter mixed Fresco DVS 1010 culture to achieve approximately $10^{5}$ to $10^{6} \mathrm{CFU} \cdot \mathrm{ml}^{-1}$. Static fermentation was performed at $37 \pm 1{ }^{\circ} \mathrm{C}\left(5 \% \mathrm{CO}_{2}\right)$ for 8 hours. The samples for analyses of counts and $\mathrm{pH}$ values were taken every 2 hours. Lb. rhamnosus GG was inoculated to the amaranth substrate after the fermentation process was completed (concentration of approximately $\left.10^{8} \mathrm{CFU} \cdot \mathrm{ml}^{-1}\right)$. After the fermentation process, pseudo-cereal substrates were stored at $6 \pm 1{ }^{\circ} \mathrm{C}$ for 14 days.
Bacteriological analyses. Total viable counts of $L b$. rhamnosus GG were determined after dilution and cultivation on Vegiton MRS agar plates (SigmaAldrich Chemie GmbH, Switzerland) and counts of Fresco DVS 1010 culture on M17 agar plates (Biokar Diagnostics, Beauvais, France) according to the ISO 15214. Inoculated Petri dishes with $L b$. rhamnosus GG were cultivated under anaerobic conditions at $37 \pm 1{ }^{\circ} \mathrm{C}\left(5 \% \mathrm{CO}_{2}\right)$ for 48 hours, and Fresco culture under aerobic conditions at $30 \pm 1{ }^{\circ} \mathrm{C}$ for 24 hours.

Evaluation of growth and metabolic parameters. Growth parameters of studied lactic acid bacteria in amaranth mashes were fitted and calculated using the mechanistic model DMFit by Baranyi and Roberts (1994). Growth and metabolic parameters were calculated from each growth curve.

Sensory analyses of flavoured mashes. Sensory attributes of an appearance (colour, consistence, incorporation of flavoured compounds), texture, aroma, taste and overall acceptability of fermented milk- and water-based mashes $\left(37 \pm 1{ }^{\circ} \mathrm{C} / 8 \mathrm{~h}\right)$, and stored products $\left(6 \pm 1^{\circ} \mathrm{C} / 7\right.$ and 14 days $)$ were evaluated by a panel of ten assessors using a fivepoint hedonic scale for each attribute ( $0-4$ points). Fresh fermented amaranth mashes and products at the end of storage period were evaluated at the same time.

Chemical analyses. Nutritional parameters-starch, content of proteins, lipids and reducing sugars were analysed in samples of used amaranth flours before and after expiry date. The fat content of the samples was determined gravimetrically after the extraction with petrol ether (Príbela, 1991). Protein content was determined according to the Kjeldahl method after the mineralization of samples in the apparatus Food Alyt IR 600 (Germany) (STN ISO 56 0512), reducing sugars were determined according to the standard procedure STN ISO 56 0512. The starch content was analysed using the polarimetric Ewers method (STN 46 1011-37).

Statistical analyses. Obtained growth parameters of studied lactic acid bacteria were analysed using Microsoft Excel 2007. The data were treated by Student t-test with the least significant difference of $95 \%$.

\section{Results and discussion}

The aim of this work was to evaluate suitability of prepared amaranth milk- or water-based mashes for both lactic acid fermentation, and the survival of selected strains of lactic acid bacteria during storage period. Amaranth mashes were selected as substitutes of flours containing gluten, which are not suitable for people suffering from celiac disease. For the people suffering from allergy to milk proteins or lac- 
tose intolerance, water-based mashes were prepared. Growth and metabolic curves of tested strains in water and milk- based amaranth mashes are shown in Figure 1 and all calculated growth parameters of observed strains are summarized in Table 1 and 2.

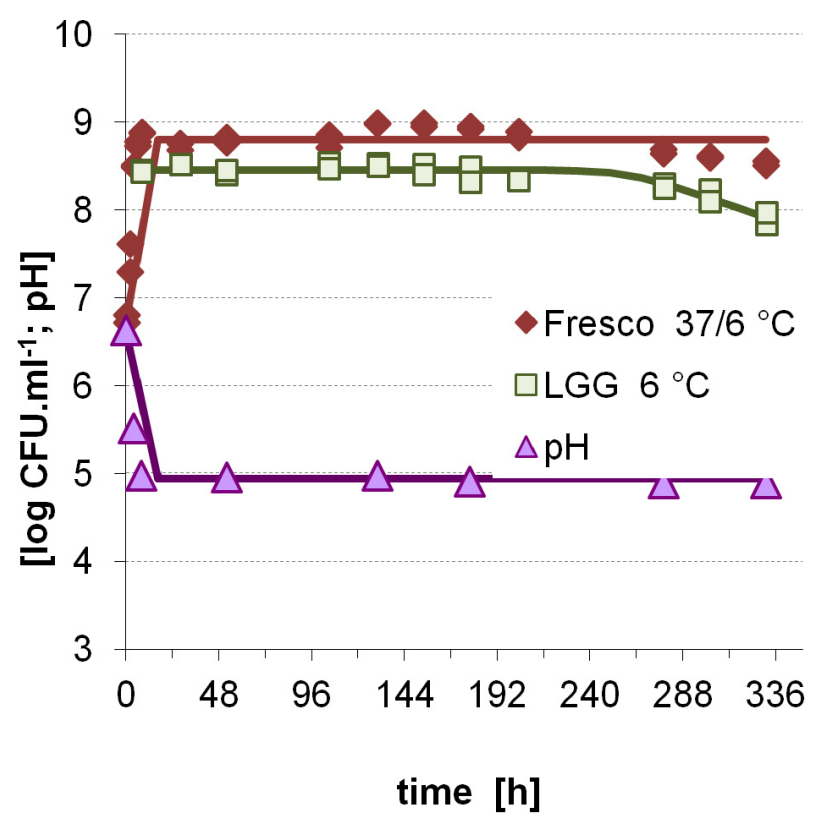

a)
In general, obtained maximal counts of monitored Fresco DVS 1010 culture after $8 \mathrm{~h}$ of fermentation process were $\mathrm{N}=10^{8}$ to $10^{9} \mathrm{CFU} \cdot \mathrm{ml}^{-1}$ from initial $\mathrm{N}_{0}=10^{6}$ to $10^{7} \mathrm{CFU} \cdot \mathrm{ml}^{-1}$, which show that tested amaranth mashes are good substrates for

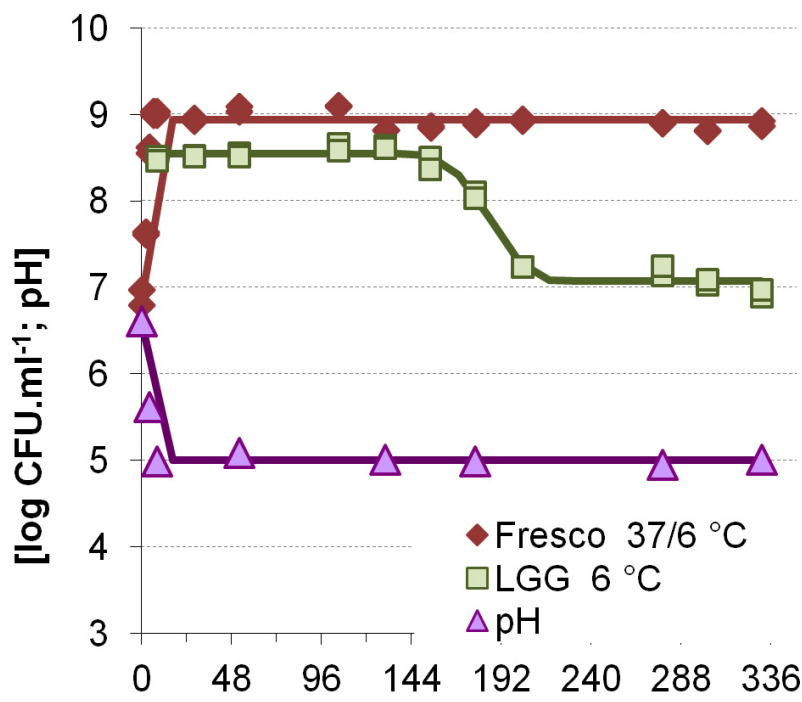

b)

Fig. 1. Presumptive counts of the cocci from Fresco DVS 1010 culture and Lb. rhamnosus GG contents in water-based amaranth (a), and milk-based amaranth (b) mashes during fermentation at $37 \pm 1^{\circ} \mathrm{C}$ and following cold storage at $6 \pm 1{ }^{\circ} \mathrm{C}$.

Tab. 1. Growth parameters of Fresco culture, $8 \mathrm{~h}$ fermentation at $37 \pm 1^{\circ} \mathrm{C}$ in amaranth mashes.

\begin{tabular}{|c|c|c|c|c|}
\hline Microorganism & $\begin{array}{c}\text { Substrate } \\
\text { Amaranth flour }\end{array}$ & $\begin{array}{c}\text { Gr } \\
{\left[\log \text { CFU.ml }{ }^{-1} \cdot h^{-1}\right]}\end{array}$ & $\begin{array}{c}\lambda \\
{[\mathrm{h}]}\end{array}$ & $\begin{array}{c}\mathbf{k}_{\mathrm{pH}} \\
{\left[\mathbf{h}^{-1}\right]}\end{array}$ \\
\hline \multirow{6}{*}{ Fresco DVS 1010} & milk & 0.436 & - & -0.250 \\
\hline & milk + caramel & 0.398 & - & -0.264 \\
\hline & milk + chocolate & 0.641 & 0.899 & -0.275 \\
\hline & water & 0.439 & - & -0.281 \\
\hline & water + caramel & 0.366 & - & -0.808 \\
\hline & water + chocolate & 0.691 & 0.996 & -0.385 \\
\hline
\end{tabular}

$\mathrm{Gr}-$ growth rate, $\lambda$ - lag-phase duration, $\mathrm{k}_{\mathrm{pH}}-$ rate constant for the decrease of $\mathrm{pH}$.

Tab. 2. Parameters evaluating behaviour of $L b$. rhamnosus GG in fermented amaranth mashes during storage at $6 \pm 1{ }^{\circ} \mathrm{C}$ when added after fermentation.

\begin{tabular}{lcccc}
\hline $\begin{array}{l}\text { Substrate } \\
\text { Amaranth flour }\end{array}$ & $\begin{array}{c}\mathbf{k}_{\mathbf{d}} \\
{\left[\log \mathbf{C F U} \cdot \mathbf{m l}^{-1} \cdot \mathbf{h}^{-1}\right]}\end{array}$ & $\begin{array}{c}\text { Stability of counts } \\
{[\mathbf{h}]}\end{array}$ & $\begin{array}{c}\mathbf{N}_{\mathbf{0}} \\
{\left[\log \mathbf{C F U} \cdot \mathbf{m l}^{-1}\right]}\end{array}$ & $\begin{array}{c}\mathbf{N}_{\text {end }} \\
{\left[\log \mathbf{C F U} \cdot \mathbf{m l}^{-1} \text { ] }\right.}\end{array}$ \\
\hline milk & -0.0348 & 156.4 & 8.50 & 6.94 \\
milk + caramel & -0.0079 & 169.2 & 8.68 & 7.18 \\
milk + chocolate & -0.0084 & 236.7 & 8.91 & 8.13 \\
water & -0.0074 & 250.3 & 8.44 & 7.91 \\
water + caramel & -0.0096 & 155.6 & 8.70 & 6.91 \\
water + chocolate & -0.0094 & 261.0 & 8.83 & 8.12 \\
\hline
\end{tabular}

$\mathrm{k}_{\mathrm{d}}$ - rate constant for decrease of the Lb. rhamnosus number, $\mathrm{N}_{0}-$ initial counts, $\mathrm{N}_{\mathrm{end}}-$ final counts after storage. 
the growth of LAB. Despite the higher content of specific nutrients in milk, presented results show similarity of growth rates in both milk- and waterbased products. Kocková and Valík (2013) and Pelikánová et al. (2015) evaluated growth of probiotic strain Lb. rhamnosus GG in cereal and pseudocereal flours and grains. At the end of $10 \mathrm{~h}$ of fermentation $\left(37 \pm 1{ }^{\circ} \mathrm{C}\right)$, population density reached counts $10^{7}$ to $\left.10^{8} \mathrm{CFU} \cdot \mathrm{g}^{-1}\right)$. In amaranth milk mashes, the growth rates of Fresco culture ranged from 0.398 to $0.641 \log \mathrm{CFU} \cdot \mathrm{ml}^{-1} \cdot \mathrm{h}^{-1}$ and in water-based mashes from 0.366 to $0.691 \log \mathrm{CFU} \cdot \mathrm{ml}^{-1} \cdot \mathrm{h}^{-1}$. The highest growth rate was calculated in water chocolate mash $\left(\mathrm{Gr}=0.691 \log \mathrm{CFU} \cdot \mathrm{ml}^{-1} \cdot \mathrm{h}^{-1}\right)$. In milk-based chocolate mash the growth rate was about $7 \%$ slower than in water product, but it was faster than in mashes with addition of caramel flavouring compound, or in product with sucrose only.

In case of water-based mash, lag phase lasted for $0.996 \mathrm{~h}$ and in milk $0.899 \mathrm{~h}$. In other cases of amaranth mashes, Fresco culture immediately started the exponential phase of growth. As a result of metabolic activity during fermentation process itself, organic acid production is observed, which causes the decrease of $\mathrm{pH}$ values in all pseudocereal substrates. Final $\mathrm{pH}$ values in water mashes dropped from initial values to 4.60-4.90 which represents 1.6-2.1 units. Pelikánová et al. (2011) reported a pH decrease of 2.5 units during fermentation of buckwheat mash with Lb. acidophilus 145 to final value 3.5 after 21 days of storage.

Milk amaranth mashes seemed to be more stable than water based mashes in term of decreasing $\mathrm{pH}$. Final $\mathrm{pH}$ values in milk mashes ranged from 4.78 to 5.01. The highest rate of reducing $\mathrm{pH}$ was calculated for the water caramel mash, when the rate of decline was 3.1 times higher than in milkbased mash $\left(-0.808 \mathrm{~h}^{-1}\right)$.

During the storage period at refrigerator temperatures $\left(6 \pm 1{ }^{\circ} \mathrm{C}\right)$, the changes in cell count were also evaluated. For probiotic food, it is necessary to keep live probiotic strain above the level $10^{6} \mathrm{CFU} \cdot \mathrm{ml}^{-1}\left(\mathrm{CFU} \cdot \mathrm{g}^{-1}\right)$. The period, when counts of Lb.rhamnouss $\mathrm{GG}$ were stable, period of stability, was influenced by the addition of flavour. The longest period of stability was noticed in case of chocolate-water mash 261.0 h (11 days). After this time counts of lactobacilli decreased $(-0.0094 \mathrm{log}$ $\left.\mathrm{CFU} \cdot \mathrm{ml}^{-1} \cdot \mathrm{h}^{-1}\right)$. In case of chocolate products, the highest counts of lactobacilli were observed at the end of storage phase $\left(6 \pm 1{ }^{\circ} \mathrm{C}\right)$. In milk mash with sucrose and caramel water based amaranth mash was recorded the biggest decline (after $156 \mathrm{~h}$ of stability time). Addition of flavours (chocolate, caramel) in amaranth mashes influenced growth rates of Fresco culture, where significant differences $(\mathrm{P}>0.05)$ were observed.

During fermentation process, biochemical changes of substrate as a result of metabolic activity of lactic acid bacteria were observed (Marko et al., 2014). Determination of chemical composition of amaranth flour is important step in assessment of the suitability of lactic acid bacteria for fermentation. General chemical composition of used amaranth flours before and after its expiry date is summarized in Table 3.

Changes in content of main nutrients in amaranth flours before and after its expiry date were determined. The percentage of starch and reducing sugars is one of the most important aspects that show suitability of substrate in fermentation technology. Decline in reducing sugars content was the most significant (31\%). Antony et al. (1996) pointed to the fact of slight increase in the content of reducing sugars during fermentation process. This fact was confirmed also in study of Marko et al. (2014), who reported the increase in reducing sugars in buckwheat flour after $24 \mathrm{~h}$ fermentation up to $47 \%$. The contents of starch, protein and fat were not reduced significantly.

Sensory analyses included an evaluation of appearance (colour, consistency, incorporation of flavouring compounds), texture, aroma, taste and overall acceptability of fermented amaranth products. Assessment of general appearance (colour and consistency) was initial and important step in evaluation of overall sensory value, and could result in exclusion of products from the area of our interest.

The results of sensory analysis of colour of chocolate and caramel mashes ranged from 2.88 to 3.5 , which indicated very good colour of flavoured mashes. Consistency of water based mashes was evaluated as smooth (in average approximately 3.7 points). In case of milk mashes, the consistency was evaluated

Tab. 3. Chemical composition (\%) of amaranth flours before and after expiry date.

\begin{tabular}{lcccc}
\hline & Proteins & Lipids & Starch & Reducing sugars \\
\hline Amaranth flour 1 & $6.56 \pm 0.00$ & $6.70 \pm 0.07$ & $69.61 \pm 0.14$ & $4.46 \pm 0.01$ \\
Amaranth flour 2 & $6.38 \pm 0.14$ & $6.16 \pm 0.03$ & $65.30 \pm 0.01$ & $3.06 \pm 0.05$ \\
\hline
\end{tabular}

Amaranth flour 1 (before expiry date) - 19. 2. 2016, Amaranth flour 2 (after expiry date) - 28. 4. 2015, the results are means \pm standard deviation of two determinations. 
as adequate smooth or with minimal lumps (from 2.65 to 3.88 ). Incorporation of chocolate (caramel) flavouring compounds ranged from 3.50 to 3.88 reflected as uniformly mixed amaranth mashes.

The major part of the assessment included taste and aroma of prepared amaranth products. The indicators of taste and aroma were divided by the descriptor which could have positive or negative effect on overall sensory value of amaranth mashes. In final flavoured products the main purpose was preservation of primary descriptors - chocolate/ caramel and pseudo-cereal aroma and taste. On the other hand, the evaluation of unacceptable aroma (taste) - rancid, foreign, was important.

Intensity of cereal aroma in case of amaranth mashes was rated as moderate that corresponds in average value of 2 . In case of caramel amaranth mash, 14 days storage period caused changes in cereal aroma that was rated as slight (1.43). On the other hand, the aroma of chocolate amaranth water based mash after $8 \mathrm{~h}$ of fermentation was evaluated with a moderate to strong intensity of cereal flavour. Several assessors identified fruit, nutty, acidic or vanilla aroma in amaranth mashes, but they were rated as unnoticeable or with low intensity. Unacceptable rancid and foreign aromas were recorded in samples but their scores indicated a low or unnoticeable intensity.

As for chocolate amaranth mashes, the descriptor denoting cereal taste prevailed in comparison to caramel mashes. Considering these findings, chocolate flavour participated on significant changes of final cereal taste of amaranth mashes. Cereal taste of amaranth mashes ranged from 1.50 to 2.86 with higher points in case of chocolate products. Chocolate and caramel taste were evaluated in similar ways and ranged from 1.50 to 2.57 . Unacceptable bitter taste was evaluated as slight or with moderate intensity. Fruit, nutty, acidic or vanilla tastes were rated as unnoticeable or with low intensity.

Final evaluation of the overall acceptability of fermented amaranth flavoured mashes (Fig. 2) is one of the most important steps pointed to the total sensory acceptance of final products.

Amaranth chocolate/caramel mashes were evaluated for overall acceptability after the fermentation with higher points when compared after the storage period except milk chocolate mash (higher point evaluation after 7 days of storage).

The negative effect of storage on overall acceptability of fermented amaranth mashes was noted. Kocková and Valík (2014) also noted negative effect of 21 days storage period on overall acceptability buckwheat product with salt fermented by $L b$. rhamnosus GG from value 3.31 to 2.44 . In other pseudo-cereal and leguminous probiotic products its decline to the points between 1 and 2 was recorded. In our case of amaranth mashes, the overall acceptance after the fermentation was from 2.31 to 2.88 which indicated satisfactory almost pleasant acceptance. However after 14 days of refrigerated storage, it decreased to points of 1.86-2.50, which indicated satisfactory overall acceptability.

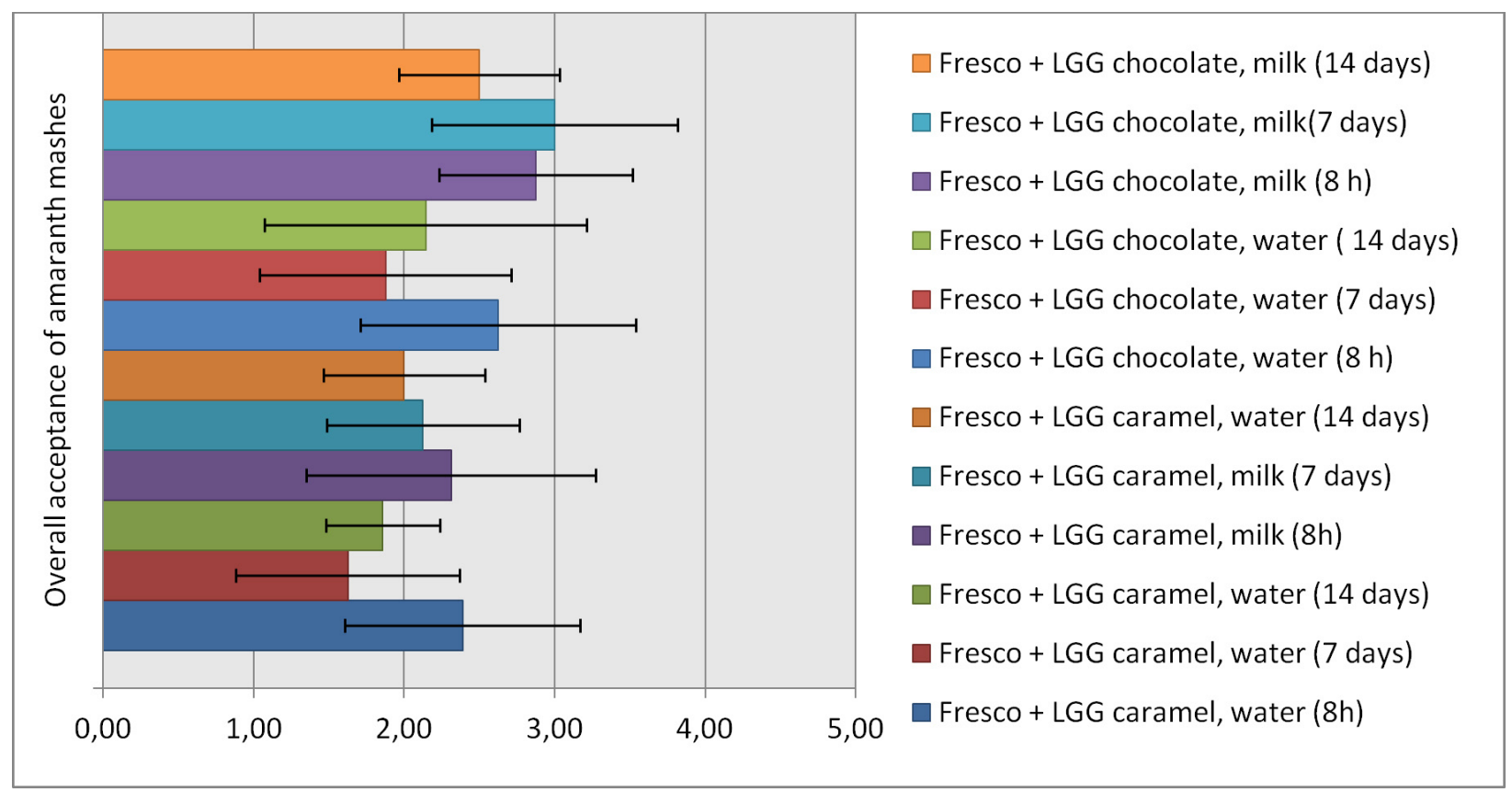

Fig. 2. Evaluation of overall acceptability amaranth flavoured mashes (LGG - Lb. rhamnosus GG). 


\section{Conclusion}

Amaranth products that were fermented and evaluated in this work were acceptable not only from the microbiological point of view but also from sensory evaluation. Based on the results, we suppose that such product can be beneficial for consumers. If they accept a shorter shelf-life, e.g. $10 \mathrm{~d}$, the products will be provided with an attractive sensory taste. Considering these findings, amaranth fermented mashes can be a suitable option for development of new probiotic foods. Thus, in this way, we can contribute to the expansion of the range of food products intended for consumption by the people suffering from celiac disease, lactose intolerance or simply provide a knowledge base to develop a new product with already known production technology.

\section{Acknowledgement}

This work was financially supported by The Scientific Grant Agency of the Ministry of Education of Slovak Republic VEGA no. 1/0495/13.

\section{References}

Amicarelli V, Camaggio G (2012) Forum Ware International 2: 4-11.

Angelov A, Gotcheva V, Kuncheva R, Hristozova T (2006) International Journal of Food Microbiology 112: 75-80.

Antony U, Sripriya G, Chandra TS (1996) Food Chemistry 56: $381-384$.
Baranyi J, Roberts TA (1994) Journal of Food Microbiology 23: 277-294.

Bhat A, Satpathy G, Gupta KR (2014) Journal of Pharmacognosy and Phytochemistry 3: 51-54.

Charalampopoulos D, Wang R, Pandiella SS, Webb C (2002) International Journal of Food Microbiology 79: 131-141.

Curry B, Crow V (2002) Encyclopedia of Dairy Sciences. New York, Elsevier Science Ltd.

Kocková M, Dilongová M, Hybenová E, Valík L (2013) Journal of Chemistry: 1-8.

Kocková M, Valík L' (2014) Czech Journal of Food Science 32: 391-397.

Liptáková D, Hudecová A, Valík L, Medved’ová A (2010) Journal of Agricultural Science and Technology 4: 88-95.

Marko A, Rakická M, Mikušová L, Valík L, Šturdík E (2014) International Journal of Research in Chemistry and Environment 4: 80-92.

Mlakar GS, Turinek M, Jakop M, Bavec M, Bavec F (2010) Journal for Geography 5-1: 135-145.

Pelikánová J, Liptáková D, Valík L' (2015) Journal of Food and Nutrition Research. In Press.

Pelikánová J, Liptáková D, Valík L’, Stančeková K (2011) Potravinárstvo 5: 53-57.

Príbela A (1991) Food analysis. Slovak University of Technology, Bratislava.

Sterr Y, Weiss A, Schmidt H (2009) International Journal of Food Microbiology 136: 75-82.

STN ISO 15214 (2002) Microbiology of food and animal feeding stuff: Horizontal method for enumeration of mesophilic lactic acid bacteria. Colony count technique.

STN ISO 46 1011-37. 2003. Testing of cereals, pulses and oilseeds. Testing of cereals. Polarimetric determination of starch according to Ewers.

STN ISO 56 0512. 1993. Methods of mill products analysis. 